\title{
ONLINE CLASSROOM MANAGEMENT AND MOTIVATION
}

\author{
Svetlana BUZU, \\ teacher, Master Degree in Education Sciences \\ PI „Mihai Viteazul” Theoretical Lyceum, mun. Chisinau \\ ORCID iD: 0000-0001-8029-7155 \\ Mariana BESCHIERU, \\ teacher, Master Degree in Education Sciences \\ PI „Mihai Eminescu” Theoretical Lyceum, mun. Chisinau \\ ORCID iD: 0000-0003-4509-5691
}

\begin{abstract}
Teaching online has become a considerable challenge for many educators. Everybody is talking about the revolution digital classroom has brought into the education world. Keeping the generation engaged, teachers need to find innovative and versatile methods, to use technology and manage the class online. Whether learning in a physical classroom or online, effective classroom management is the key component to a productive environment. Although, students are not all present in a single room, teachers must be intentional about managing student behavior and engagement in an online setting. Some challenges can be anticipated, and online classroom management strategies effectively overcome those challenges.

Online learning focuses on a wide range of technological based learning platforms, delivery methods, and the integration of educational technology components into the learning environment. This article will address online education, its strengths, limitations, online teaching tools, professional development, best practices, and an evaluation of a personal online experience.
\end{abstract}

Keywords: online teaching and learning, classroom management, distance learning, technology, safety.

\section{MANAGEMENTUL CLASEI DE ELEVI ÎN CONTEXT ONLINE ȘI MOTIVAREA}

Rezumat. Predarea online a devenit o realitate didactică cu multiple provocări pentru majoritatea cadrelor didactice. Totodată, este incontestabilă revoluția clasei digitale în lumea educației. Pentru menținerea interesului elevilor în procesul de învățare, profesorii trebuie să găsească metode inovatoare de utilizare a tehnologiilor moderne și de asigurare a eficienței managementului educațional a clasei în contextul de activitate online.

Indiferent de modul de predare - în clasa fizică sau online, gestionarea în mod eficace a acesteia este componenta-cheie a unui mediu productiv. Deși nu toți elevii sunt prezenți fizic, profesorii trebuie să se implice activ în aplicarea unor strategii de adaptare în a stăpâni comportamentul și angajamentul elevilor într-un mediu online. Unele provocări în asemenea situații pot fi anticipate.

Învățământul la distanță se concentrează pe o gamă largă de platforme de profil, bazate pe tehnologii de ultimă oră, metodologii și integrare a componentelor educaționale, în funcție de mediul de instruire. Autoarele prezintă reflecții pe marginea noului sistem de învătare online, avantajele și punctele slabe ale unor instrumente digitale, metode și strategii de predare, având ca bază experiențele personale.

Cuvinte-cheie: predarea și învățarea online, gestionarea clasei, învățământ la distanță, tehnologii informationale, siguranță.

\section{Introduction}

Traditionally, teaching has been a face-to-face experience. The interaction between the teacher and the student(s) and among student participants plays a strong role in shaping the learning experience. Through online and hybrid learning (hybrid refers to those courses that combine face-to-face meetings with an online component) the face-toface interaction is lost. This loss is of great concern for both teachers and school children.
Online learning requires engaging activities for students. As a result, teachers need time to understand what their challenges are or what interests their students share. Using this information a teacher can build an online classroom management plan that will provide opportunities for making the process of learning an interactive one.

This article reviews current literature about advantages of online learning, the needs of teachers and students involved in online teaching and learning. 
The usage of a large variety of technological modalities, learning practices, and diversified methods may enrich the learning environment. In addition, teachers should establish communication rules in the online environment, this step being crucial for a harmonious classroom management. Teachers are working with numerous students, some of whom do not understand online communication etiquette.

Thus, it is imperative for them to know the consequences and penalties of using unacceptable communication tools, in case they do not meet teachers' expectations the same as in a traditional classroom. Some experts state that online classroom routine makes the lesson more productive for both teachers and students. For instance, the beginning of the lesson might look like two minutes of free talk time, typing their response to one of the teacher's questions in the chat box or on a piece of paper and hold up to the camera. This way the teacher will check the students' presence and involvement. Due to the nature of teaching, professors are necessarily interested in teaching effectively and also, the issues related to successful student learning in an online delivery format as well.

For these reasons, the review of literature will focus on the advantages of online teaching and learning, the needs of teachers, and the needs of students in order for both groups to have a successful online learning experience.

\section{Online Teaching and Learning}

Why online distance learning and why now? Online distance learning meets the needs of an ever-growing population of students who cannot or prefer not to participate in traditional classroom settings.

These learners include those unable to attend traditional classes, who cannot find a particular class at their chosen institution, who live in remote locations, who work full-time and can only study at or after work, and those who simply prefer to learn independently. The minimum requirement for students to participate in an online lesson is access to a computer, the Internet, and the motivation to succeed in a non-traditional classroom.

Online learning provides an excellent method of course delivery unbound by time or location allowing for accessibility to instruction at anytime from anywhere. Learners find the online environment a convenient way to fit education into their busy lives. The ability to access a course from any computer with Internet access, 24 hours a day, seven days a week is a tremendous incentive for many of today's students [7].
The educational delivery system is changing because of technological advances. Students now have greater autonomy at directing their learning toward their specific needs rather than approaching it circuitously [7].

Maeroff (2003) reports that, „E-learning has come on the scene to augment and sometimes supplant the traditional classroom" [9].

\section{Discussion}

The online instructor plays a vital role in developing and maintaining an effective online learning environment and must possess a unique set of tools to perform successfully. Some instructors from the traditional classroom environment will easily adapt to the online model, while others may find the transition challenging. Reflect on your teaching style, circumstances and technical skills to see if teaching online is right for you.

The online facilitator should be open, concerned, flexible, and sincere. An online instructor must be able to compensate for the lack of physical presence in the virtual classroom by creating a supportive environment where all students feel comfortable participating and especially where students know that their instructor is accessible. Failure to do this can alienate the class both from each other and from the instructor and would make for a very weak learning environment. Online students are as busy, or busier, than anyone else in today's hurried world.

An online instructor should be willing to give individual attention to students who may need extra help. Being sensitive, open and flexible is mandatory for success in the online realm.

One of the most important elements of planning and managing online courses is instructors' recognition of the fact that although there are a wide array of educational technologies and course management tools available for online teaching, not all of these technologies are appropriate matches to the subject taught and the teacher's pedagogical style and strategies.

As such, it is very important that instructors ensure that pedagogical principles drive the use of technology rather than the other way around. Instructors must strive to achieve certain learning standards, regardless of the medium through which they are teaching.

The first step in the planning process involves the development of learning objectives. The importance of learning objective development and communication is highlighted throughout the literature. 
Following the development of clearly defined learning objectives and the special needs of students, instructors may begin to select the technological option best-suited to provide students with a constructive feedback.

Delayed feedback may result in the students' sense of isolation or cause lack of interest during online lessons. A lack of immediate feedback is extremely frustrating for online students and can impede progress [9]. „The student who does not receive a response to the own comments may feel as he is crying out in a wasteland and no one cares" (Maeroff, 2003).

Therefore, giving feedback on time can be done via audio podcasts like Vocaroo or videoconferences with Zoom or Google Meet where important issues can be discussed, encouraging engagement, interaction with other participants, and collaboration that will lead to students' success. Using the feedback provided by the students and the results from analyses of the learning outcomes enables a teacher to make decisions on what online learning activities best contribute to student learning and what framework best addresses pedagogical and technological issues. In addition, the student feedback helps to decide which online components are less liked and do not result in a positive learning experience.

One tool to help assess the effectiveness of the online tools and the quality of the combined learning environments is classroom action research. Classroom action research helps a teacher to try out new online tools, implement those that are successful, and gather student feedback, reflect, and revise to further improve and develop the course [12].

Also, emoticons like laughter, applause, agree and disagree icons are very popular among all learner groups in both synchronous and asynchronous instruction. A single positive comment permits the students realize that their teacher is concerned about their learning. From my experience, when comes to assignment and grading, it is wise to give students fewer, but more complex assignments that will allow students prove their knowledge and skills.

Autonomy is also the key to motivation, because the students are given the choice to use their own sources or apps, according to their own interests and competences when completing their assignment, creating products like presentations, posters, etc. They can choose Book Creator, Flipsnack, An- imoto, Screencast-o-Matic, Power Point, Prezi and others. Assessment activities are ideally learning activities, opportunities to motivate and enhance students' knowledge. Teachers have a great variety of apps to use while evaluate students like Liveworksheets, Socrative, Kahoot, Mentimeter etc. For example, Exam.net where students can access the exam with a simple key and it doesn't allow the student leave until completed.

An online instructor should be able to accept the value of facilitated learning as equal to the traditional model. If a teacher feels the only way that true learning can take place is through the traditional means of educating in a classroom, the person is generally not a good fit for the online paradigm. This is $\mathrm{OK}$, but we must be honest with ourselves. Both an accelerated learning model and the online process depend on facilitative techniques for their success.

The online classroom requires new teaching strategies and instructional techniques; you should not try to recreate the on-ground classroom in the online paradigm. The person leading a successful online class must be a proponent of facilitative learning, and have confidence in the system in order to make it work.

As with any learning medium, the use of the Internet in distance and online learning has limitations, as well as strengths. Social interactions within the online environment are influenced by communication approaches designed within an online program [10].

Another difficult part in building an online environment is that there is limited opportunity for establishing trust. Developing a deep level of sharing may sometimes be problematic. Ethical practices such as honesty, integrity and reliability may not always be present in student practices. The belief that there are more opportunities for cheating, creating falsehoods, and producing dishonest work perpetuates this view. Students' learning style preferences impact upon the quality of their attitude toward a particular instructional tool, but an instructor's consciousness of the importance of learning style preferences may help him or her to adapt tools for teaching that address the learning needs of students with multiple learning style preferences. Simpson (2015) recommended that one important alternative consideration when designing online instructional tools is to teach students to use strategies that will succeed in learning situations that do not favor their preferred learning style. 
Technical problems and solutions for technical support may also hinder the effectiveness of online learning.

\section{Conclusions}

As a final note, due to current global extreme events, education is changing and we cannot teach by old standards ignoring the needs of students. Thus, teachers need to adapt to new requirements and ensure the usefulness and efficiency of the lessons by using authentic materials and interesting that will motivate and encourage students on their path to success.

Design and delivery of online courses that embrace community, curriculum, and assessment, as well as actively engage students in the learning process are significant for sustaining and building the online lesson.

Effectiveness in the online environment points out the importance of being supportive and contributive to a sense of togetherness for development of relationships and overall success of coursework. Students' interest and relevance of the content influences their work performance for achievement of goals. Finding the right combination of online and traditional teaching and learning tools to meet the broad array of learning styles remains one of the greatest challenges in today's teaching environment.

Considering teaching and learning styles when incorporating online teaching and learning tools can help a teacher to better address student learn- ing needs. Student learning is strongly influenced by the teacher's ability to communicate the subject matter. Creating a successful learning environment therefore heavily depends on the creativity of the teacher. It will be important to decide which course components can be enhanced most effectively via the Internet and which can be done more effectively in the traditional classroom.

Only a continuous assessment of learning and teaching styles and Internet tools will help to appropriately address these issues and best meet student-learning needs. We believe that in a world where lifelong learning is essential for students' long-term success; only students who experience learning in positive learning environments are likely to continue their journeys toward becoming successful lifelong learners.

An efficient online learning environment demonstrates technology-rich, research-based instructional and learning strategies that facilitate learning, and classroom management within the course room experience. The electronic movement has evolved into a science, which engages best practices; some from bricks and mortar institutions, and others, which emerged from a highly diversified cultural, academic. The online learning environment, once devoid of personal communication, is now fulfilled with approaches that help students feel a sense of community and partnership while meeting their learning needs.

\section{REFERENCES}

1. Allen I.E., Seaman J. Learning on Demand: Online Education in the United States. Babson Survey Research Group, Needham, M.A., 2009: Sloan-C. Disponibil: http://sloanconsortium.org

2. Allen I.E., Seaman J. Online Nation: Five Years of Growth in Online Learning. Newburyport, MA: The Sloan Consortium, 2007. Disponibil: http://www.sloan-c.org/publications/survey/online_nation

3. Alley M. Foundation of Educational Theory for Online Learning. In: Anderson T. Theory and Practices of Online Learning, Canada AU Press, Athabasca University Press, 2008, pp. 16-44.

4. Barr R.B., Tagg J. From Teaching to Learning - A New Paradigm for Undergraduate Education. In: Change magazine, 27(6), 1995, pp. 13-25.

5. Bonk C.J. The World is Open: How Web Technology is Revolutionizing Education. San Francisco: „Jossey-Bass”, 2011.

6. Henry A. Digital Games and ELT: Bridging the Authenticity Gap. In: E. Ushioda (Ed.) International Perspectives on Motivation. Basingstoke, UK: „Palgrave Macmillan”, 2013, pp. 133-155.

7. Kearsley G., Moore M. Distance Education: A Systems View of Online Learning. Wadsworth Publishing Co., Belmont Ca, 2012. 
8. Kelderman E. Online Programs Face New Demands from Accreditors. Chronicles of Higher Education, 2011. Disponibil: http://chronicle. com/article/Online-Programs-Face New/129608/.

9. Maeroff G.I. A Classroom of One: How Online Learning is Changing our Schools and Colleges. New York: Palgrave, Macmillan.

10. McInnerney J.M., Roberts T.S. Online Learning: Social Interaction and the Creation of a Sense of Community. In: Educational Technology \& Society, 7(3), 2004, pp. 73-81.

11. Radford A.W. Learning at a Distance: Undergraduate Enrollment in Distance Education, Courses and Degree Programs. United States Department of Education, Stats in Brief, 2011.

12. Simson M., Smaldino S., Zvacek S. Teaching and Learning at a Distance, 6th edition, IAP, 2015, USA.

13. Sockett, G. The Online Informal Learning of English. Basingstoke, UK: „Palgrave Macmillan”, 2014.

14. Tapscott D. Grown Up Digital: How the Net Generation is Changing Your World. NewYork: „McGraw Hill”, 2009.

15.Toffoli D., Sockett G. University Teachers' Perceptions of Online Informal Learning of English (OILE). 2015.

16. Trinder R. Informal and Deliberate Learning with New Technologies. In: ELT Journal, 71(4), 2017, pp. 401-412.

17. Wong P. Online and Face-to-Face Students' Perceptions of Teacher-Learner Interactions. A Preliminary Examination. In: Distance Learning. 2(5), 1-7, 2005, p. 5. 